Piers Kelly

\title{
Excavating a Hidden Bell Story from the Philippines: a Revised Narrative of Cultural-Linguistic Loss and Recuperation
}

\begin{abstract}
Stories of hidden valuable artifacts are told in many parts of the Philippines. One such tale is of a church bell, concealed to prevent theft but now beyond reach (Motif V115.1.3, Sunken church bell cannot be raised). Typically, these stories are transmitted orally. However the small Eskaya community of southeast Bohol maintains a written version of a lost-bell tale included in a larger intergenerational archive of handcopied literature. Since the early 1980s, the Eskaya have been an object of media interest for having consciously created their own "indigenous" language, writing system and literary tradition. This paper examines the meanings of the Eskaya variant of the lost-bell story in the context of community aspirations for recognition as an indigenous minority. In the Eskaya version, pre-Hispanic native faith is valorized over the corrupted Christianity introduced by Spain. The deliberately concealed church bell and its promised future retrieval recapitulates wider postcolonial narratives of cultural-linguistic suppression and revitalization, underscoring the agency of Eskaya people in their retrieval (or reinvention) of a pre-colonial indigenous identity.
\end{abstract}

Tales of lost treasure loom large in the Filipino imagination. American silver dollars, Japanese gold bars, and the misappropriated millions of former president Ferdinand Marcos are all presumed to lie somewhere close yet inaccessible, tantalizingly out of reach for ordinary folk. One intriguing lost-treasure story, attested in various parts of the Philippines, is the tale of a 
church bell hidden by locals to prevent it from falling into the wrong hands; yet in its new hiding place, the bell becomes unreachable even to its rightful owners and its retrieval is fraught with danger. I argue that these narratives of loss and deferred recovery have a special resonance for colonized people coming to terms with dispossession. According to this reading, suppressed culture — represented as a reified and valuable object—exhibits its own powerful agency. Under the threat of plunder it is rendered invisible but is never wholly obliterated, and its recuperation must be performed with great care lest it wreak misfortune on the unworthy.

One detailed variant of the lost-bell story is told by members of the little-studied Eskaya cultural minority of southeast Bohol (Fig. 1 and Fig. 2) who have produced a written version of it within a larger corpus of literature that has been recopied for at least the past four generations (Ramos 1980; Cuizon 1980; Martinez 2003; Kelly 2012a). The Eskaya variant lends itself particularly well to a postcolonial reading and sheds light on the significance of lost-object stories in the Philippines at large. By examining the historical context of this tale, its folkloric intertextuality and the interpretations brought to bear on it by Eskaya people themselves, I hope to explicate its significance as a historical-political allegory and, ultimately, address the question of what it means to be a postcolonial subject in the Philippines. In my analysis of the Eskaya variant, the rescue and concealment of the bell is a recursive metaphor of native selfdetermination and resistance. Nested within an expanding series of wider moral meanings, the bell operates as a kind of pure signifier, standing simultaneously for indigenous language, religious belief, inalienable ownership, authentic culture, and nationhood.

\section{$<$ Figure 1 >}

\section{$<$ Figure 2>}




\section{The Eskaya}

With an estimated population of around 3000 people inhabiting five villages in Bohol in the southern Philippines (Fig. 2), the Eskaya community represents a unique sociological phenomenon. ${ }^{2}$ Having come to wider public attention in early 1980 , when touring agricultural advisers "discovered" the isolated community in the densely forested uplands of Bohol, the Eskaya were briefly an object of popular curiosity in the local media (Kelly 2012b). Though most Eskaya choose to identify themselves with the label "indigenous," the Eskayan languagewith its own complex script (Kelly 2016) — has only been positively traced to the 1930s and is widely believed to have been invented. ${ }^{3}$ Indeed, Eskaya community leaders themselves are candid in attributing the origins of their language to the creative ancestor Pinay, an entity of uncertain age who is regarded as their pinal inmunsiktur (Eskayan: "first pope") (Kelly 2012a, 2012b). Moreover, Pinay's language is celebrated as Bohol's true language, suppressed and almost wiped out by successive waves of foreign colonists. Today Eskayan is spoken and written in a few special domains by about 20 percent of the Eskaya population; the language of day-today communication in the Eskaya villages is Visayan (also known as Cebuano), the dominant language of the southern Philippines.

Language is not the only recent expansion of the local cultural repertoire: traditions of Eskaya dress, music, dancing, governance, spirituality, and literature are understood, in Eskaya oral history, as dormant but authentic indigenous practices that were either revived or inspired in the lifetime of a former leader by the name of Mariano Datahan (ca. 1875-1949). This has created something of a paradox. On the one hand, the Eskaya community — with its hereditary chieftains, local laws, language, and folklore-neatly conforms to popular notions of how a Filipino indigenous community should look and behave. On the other hand, the apparently 
shallow time-depth for Eskaya cultural practices and the undisguised creativity of their origins undermines the supposed "timelessness" and "naturalness" associated with popular archetypes of indigeneity. What is certain, however, is that the existence of Eskaya community in Bohol long predates the promulgation of indigeneity as a juridical concept in the Philippines (Kelly 2014), and thus Eskaya culture cannot easily be dismissed as a hoax perpetrated on a gullible public, nor as a play for government assistance as some have argued (Logarta 1981). Indeed, documentary evidence indicates that the community can be traced as far back as (at least) 1902 when US authorities were reporting on the activities of dissident groups in the aftermath of the PhilippineAmerican War (Philippine Commission 1904, vol.3, 116). Moreover, it is a well-established pattern among other Philippine cultural minorities that those skilled in verbal arts tend to assume leadership roles and become arbiters of (sometimes rapid) change, particularly in conditions of cultural stress (Meñez Coben 2009, 12, 230-231, 360). If, therefore, the Eskaya "revival" initiated by Mariano Datahan was not primarily an assertion of indigenous identity or a spurious quest for minority rights, then what was it?

There is no single or satisfying answer to this question and scholarly studies of the Eskaya are still remarkably few. Perhaps due to the distracting debates over cultural authenticity and sensational speculations in the local media — for example, that the Eskaya are descendants of Etruscans (Payot 1981; Abregana 1984), a lost tribe of Israel (Tirol 1993), or a cult (Logarta 1981; Peralta 2005) - the important task of describing and understanding Eskaya cultural forms has not received the full attention it deserves. Nonetheless, several committed Filipino graduate students have produced short ethnographic sketches (Hinlo 1992; Martinez 1993; Orcullo 2004; Estorba 2006) and preliminary linguistic descriptions (Torralba 1991a, 1991b, 1993; Consul 2005). My own research has centered on a descriptive and historical analysis of the idiosyncratic 
language and script, used today by approximately 550 people in Taytay, Biabas, Lundag, and Cadapdapan (Fig. 2). As an Australian government intern, I undertook fieldwork for this study via the service center of the National Commission on Indigenous Peoples in Bohol from late2005 to the end of 2006. During this time I conducted regular visits to the villages of Biabas and Taytay where I was permitted to photograph thousands of pages of Eskaya manuscripts—some of which were carved on wood - and to witness readings and scholarly discussions of the texts. Later, as a PhD scholar, I returned for further fieldwork in Biabas, Taytay, and Cadapdapan over the dry seasons of 2009 to 2011 . This later research was also centered on the form, structure, and history of the Eskayan language but incorporated the collection of relevant oral histories, genealogies and local folklore.

My grammatical and lexical analysis has indicated that Eskayan is not related to regional languages, but appears to be planned as a mixed language fusing a modified Visayan morphosyntax (Kelly 2012c) to a lexicon that has taken phonological and semantic inspiration from Spanish, English, and regional Visayan dialects (Kelly 2012a). This analysis is consistent with the traditional Eskaya attribution of the language to a creative ancestor, but whether the pope "Pinay" was a real or mythological individual cannot be known. For the purposes of analysis I have treated Pinay as a heuristic, suggesting that he may have designed Eskayan as a strategic reaction to the dominance of colonial languages including the prestige dialect of Visayan introduced from the neighboring island of $\mathrm{Cebu}^{4}$

The relative scarcity of archeological and archival sources for the southeast uplands of Bohol means that historical context in which the culture hero Pinay's language was created is harder to delineate. According to oral histories and genealogies, the immediate descendants of Eskaya people alive today were members of the Iglesia Filipina Independiente (Philippine 
Independent Church) from its foundation in 1902, and their leader Mariano Datahan enforced an austere and highly codified lifestyle for the new converts. Wars, occupations, and migrations also feature prominently in Eskaya oral history in which narratives are framed by Bohol's famous Dagohoy Rebellion (1744-1829), the Philippine-American War and subsequent displacement of internal refugees in Bohol (1899-1902), and the Japanese occupation (1941-1945). It is well known that patriotic millenarian movements proliferated in the Philippines from the 1890 s onward, and were given further impetus by the Philippine-American War (Sturtevant 1976, 118). Like the Eskaya community, these movements were often advanced by talented verbal artists who promoted strict behavioral regimes, and adherents referred to their leaders as "Popes" (Meñez Coben 2009, 14, 231; Kelly 2012a, 251-262). However, while linguistic, historical, and genealogical data are invaluable for painting a detailed contextual picture they tell us less about the actual motivations and inspirations of the community itself, and of what it means to be Eskaya today.

\section{The Eskaya Literary Corpus}

It is here that an intertextual analysis of Eskaya traditional literature- a hand-copied archive of folklore and expository texts — can provide invaluable insights. Within this corpus, the brief story referred to as "The White Bell" is a short and fascinating variant of a classic lost-bell story from the Philippines, and provides an enriched perspective on Eskaya ways of being. Before analyzing "The White Bell" in detail, it is worth briefly describing the larger corpus of Eskaya literature to which it belongs and its attendant practices of literary reproduction, transmission, and interpretation. 
According to Eskaya oral history, the revitalization of Eskaya culture began after Mariano Datahan discovered carved wooden tablets written in a forgotten language. Supposedly carved by Pinay, they had been stored in cave for safekeeping against the destructive policies of the local friars who were bent on burning all the native literature. After deciphering Pinay's language, Datahan began to teach it to his followers in the village of Biabas (Fig. 2), and to reacquaint them with their forgotten folklore. In another account, it was Datahan himself who received direct linguistic inspiration from the ancestral past, and he wrote down the language and stories on wooden tablets which were then stored away for protection in a cave by his followers. Faustina Viscayda, who died in 2009 at the age of 85, recalled that as a young girl she acted as a scribe for Datahan, who dictated these stories to her and to other scribes who recorded them in writing for the first time (Martinez 1993). In any event, Datahan is credited with the feat of reanimating the lost Eskayan language and literature of Pinay and of retransmitting it to his followers.

Nowhere in the literary corpus itself, comprising over 25,000 words of handwritten text, is there any explicit mention of native records being destroyed by the Spanish nor of Eskayaninscribed tablets being hidden in a cave for protection, but Eskaya people regard these events as factual and even self-evident — the cave in question can be found a short distance from Biabas. This oral explanation has become central to the corpus of written Eskaya literature and continues to inform its local interpretations.

Today, five Eskaya stories form what I refer to as the "Canonical Literature." These are taught in classes that take place on Sundays in community-organized schools in Taytay, Biabas, and Lundag. Using the Eskaya script, students are expected to transcribe these stories as a necessary part of their linguistic and cultural education (Fig. 3). The literature is always 
reproduced with an accompanying official translation such that Eskayan is found on the left page of the notebook with its Visayan rendering on the facing page, or vice versa (Fig. 4); the Eskayan script is adaptable to both languages. In my own assessment of these facing-page documents, it is apparent that the Eskayan text is actually a translation from a Visayan original and not the other way around..$^{5}$ Non-canonical texts are rarely introduced to the traditional school system but are read aloud and recopied by Eskaya students in informal study groups. While most stories are written in both languages, certain Eskayan texts are available only in Visayan, and one story is in Eskayan only.

\section{$<$ Figure 3 $>$}

\section{$<$ Figure 4 $>$}

Eskaya stories are today treated as authorless texts - a fact which has implications for their reproduction and modification. Despite the value placed on scrupulous copying, no two Eskaya texts are identical. Confusingly, it is often impossible to know where one text ends and another begins. From notebook to notebook, near identical stories may go by several different names, while texts with the same name can differ considerably in their content. The proliferation of differences across texts does not seem to have generated any conflict over which represent the "true" or orthodox versions, though chieftain Juan Datahan has expressed the view that the texts in the foundational Eskaya village of Biabas (Fig. 2) are the most authentic as they are more proximal to Mariano Datahan (Martinez 1993, 78). Nevertheless, oral interpretations and retellings of Eskaya literature are relatively consistent across communities. 
The critical importance of writing to Eskaya history and cultural identity defies any easy association of minority Philippine communities with oral tradition. ${ }^{6}$ Writing is vital to the creation mythology of Eskayan: the ancestor Pinay developed writing from the human body and it was by means of a written channel that Pinay's creation was imparted to Mariano Datahan. According to one traditional text a language without writing is simply hangin sa baba (Visayan: "air in the mouth") (Martinez 1993; Kelly 2012a), while cultural legitimacy hinges on the form this writing takes. Even today, claims and counterclaims over the antiquity and authenticity of the Eskayan language in Bohol's media are most frequently oriented to the script, and tend to presuppose that writing is the true essence of the language. These debates reflect an ongoing preoccupation in the Philippines with pre-contact literacy as an index of cultural sophistication, and with paleographic remains as material evidence of indigenous civilization. The story of Pinay's prudent decision to hide Eskayan tablets in a cave must be seen in the context of a belief common throughout the Philippines that Spanish missionaries destroyed all the native archives upon their arrival in the islands in order to make way for their own governing structures (Pajo 1954; Zaide 1959; Ileto 1979; Beyer 1979; Aguilar 1994; Ongsotto and Ongsotto 2002). Given the policies of Bishop Diego Landa de Calderon, who notoriously ordered the destruction of Maya codices in Mexico in the early-sixteenth century, the suppression of native literature is certainly plausible. In the Philippines, however, no historical evidence favors the view that such conflagrations ever took place. ${ }^{7}$

\section{Lost Bells and Other Treasures}

The story of a bell hidden in the depths of the Abatan River on the west coast of Bohol is recounted and recopied by members of the Eskaya community, but the tale itself is not original 
to the Eskaya and is in fact relatively well known in other communities throughout the island. In its simplest form, a bell belonging to the native people is said to have been requisitioned by Spanish priests who hoisted it into the bell tower of a church. But the bell was reclaimed by the people who took it to the Abatan River and let it sink so that the foreigners would never again be able to get hold of it (Motifs D1654.10.1, Bell sunk in sea can be raised only under certain conditions; V115.1.3, Sunken church bell cannot be raised). A more detailed local variant casts Tamblot, a seventeenth-century Boholano rebel, as the hero. Tamblot had been given the bell by the Spanish authorities, but when a priest wanted to take it back to install in a church, Tamblot refused and hid it in a large bend of the river. To this day, it is said that the bell can be seen glinting under the water's surface at dusk.

Further variants within the lost-bell cycle are recorded beyond Bohol. According to legend, the bell from the church of San Francisco de Manila was found floating in the bay and all the Spanish religious orders gathered to help bring it to land. But despite the small size of the bell, it proved too heavy and only when all the clergy had left the scene did it allow itself to be lifted with surprising ease. The bell is said to sound without being rung (de los Reyes y Florentino 1889; compare Motifs F960.1.4, Bells ring without human hands when a saint is born; V222.6.1, Church bells ring without aid of human hands at death of holy person).

In the Bicol region of the northern island of Luzon, a church bell was said to have been hidden in a lake from marauding Moro pirates who had heard it ringing as far away as Mindanao. But after the pirates departed, the people were unable to recover the bell and their efforts provoked a mighty storm (Ratcliff 1951, 233). Similarly, in Mindoro Oriental, a golden bell was said to be buried to prevent its capture by approaching Moro pirates. Soon after, a tree grew above the bell, bearing bell-shaped wax apples known as makopa (Eugenio 1993; compare Motif 
F979.6, Tree grows through saint's bell). Further north in Ilokos, a story is told of a magic rainmaking bell given to the villagers by an anito ("nature spirit"). The people in the vicinity grew jealous and tried to steal it, so the villagers buried the bell in the forest and a great drought ensued. Sadly, nobody could remember where the bell was buried. A boy wandered into the forest and found a wax apple tree with its bell-shaped fruit. He alerted the villagers who dug beneath the tree and found the bell, ending the drought (Eugenio 1993). Another tale recounts that the old township of Bay, on the shores of Laguna de Bay south of Manila, sank into the water and that the bell at the top of the church's bell tower can be seen when the water is clear (Ratcliff 1949, 275). ${ }^{8}$

More commonly, tales of buried gold, silver, and generic treasure are recounted throughout the Philippines. In Bohol alone, there are many such recuperation narratives in which a lost artifact is hidden by a heroic ancestor in order to be retrieved by a future hero, usually with the prohibition that the object must be reclaimed by the right person at the right time or disaster will ensue (ATU 745A, Treasure always comes to predestined owner). The treasure of Bohol's most famous rebel, Francisco Dagohoy (1724-c. 1782), ransacked from church estates, is said to be buried in caves in the cliffs of Kailagan, but anyone who seeks it will die unless they use it to fight for the freedom of the Boholano people. Just as Tamblot's bell can be seen glinting under the surface of the water at dusk, Dagohoy's treasure is reputed to shine from the cliff-face at sunset (VB Tirol 1968, 53).

A more recent recuperation narrative in Bohol concerns the World War II occupation. Japanese soldiers are believed to have buried bars of gold at Mount Puwawan, but those who search for them risk losing their lives. The story goes that a group of American engineers planned to bulldoze the mountain to find the treasure but some members of the group died from 
mysterious illnesses so the project was cancelled (Aparece 2003, 104). Lucetta K Ratcliff has collected a thematically similar tale from the Botocan River in La Laguna province $(1949,264$ 265). Set "during the guerrilla warfare between the Americans and Filipinos," the story describes a tree covered in mysterious inscriptions in an unrecognized language that grew in front of a waterfall. Behind the waterfall lived a wealthy water spirit who gave a poor peasant girl money and golden jewelry, with the injunction not to tell anybody where she got it from. When her mother eventually compelled the girl to tell the truth, her new treasure disappeared. After the Americans learned of the treasure in the cave they tried obtain it but were continually thwarted. Today, "whenever an American or any foreigner goes there, even if it be Mr. William H. Taft [the US Governor-General of the Philippines 1901-1904], it rains heavily although the sun shines brightly" $(1949,266)$.

As an outsider to the Philippines these stories have intrigued me for what they appear to reveal, not about the locus of lost wealth but about the postcolonial national psyche. A striking common theme is that of resources unjustly withheld from their deserving recipients, corresponding to periods of colonial occupation and political suppression. Just as the original confiscation of resources was overshadowed by violence, there is always a danger associated with their recovery. Here, a kind of malignant agency is ascribed to the treasure such that the undeserving claimants are always punished for their presumption. In the Mount Puwawan and Botocan River tales, the Americans - themselves participants in the colonial exploitation-are justly stopped in their tracks for their greed and hubris by environmental conditions beyond their control. Dagohoy's treasure is regarded as the rightful property, not of the Spanish churches from which it was looted, but of future rebels. Likewise, the white bell in the Eskaya variant of the tale belongs exclusively to the resurrected martyrs of Bohol. 
I argue that these stories are not just about lamenting a loss of resources but are also a way of accounting for a perceived cultural deficit in terms of intangible heritage, as alluded to, for example, in the mysterious language carved on the tree in the Botocan River tale. In other words, they serve as a cryptic response to what the preeminent Filipino nationalist José Rizal described as "the specter of comparisons" (el demonio de las comparaciones), or the temptation to compare the Philippines unfavorably with other nations (Rizal 1886; and see especially Anderson 1998). As Rizal would later put it in his account of the Filipinos' historical humiliation:

Then [after attachment to the Spanish crown] began a new era for the Filipinos; little by little they lost their old traditions, the mementos of their past; they gave up their writing, their songs, their poems, their laws in order to learn by rote other doctrines which they did not understand, another morality, another aesthetics different from those inspired by their climate and their manner of thinking. Then they declined, degrading themselves in their own eyes; they became ashamed of what was their own; they began to admire and praise whatever was foreign and incomprehensible; their spirit was dismayed and it surrendered. ([1889-1890] 1972, 130-131)

This statement precedes a narrativized explanation of how Filipinos at last began to rediscover and reassert their native pride in the face of Spanish opposition, a sentiment that would ultimately lead to Rizal's own execution in 1896. Nonetheless, former colonizers continued to present native Filipino culture as imitative and empty — a void to be filled in with original content from the West (see commentary in Cannell 1999, and Thomas 2012). ${ }^{9}$ This discourse has generated a kind cultural inferiority complex popularly termed by Filipinos today as "the colonial mentality" (Root 1997; David and Okazaki 2006). Recuperation stories provide a 
subversive counter-narrative to the colonial mentality whereby the debilitating comparison (or its specter) is forestalled. The legitimate culture and political sovereignty of the colonial subjects is embodied as a suppressed treasure that is never completely eliminated but merely suspended with the promise of future recuperation. It is here that the lost-treasure narratives articulate with another classic recuperation motif of Philippine folklore - that of the hari sa bukid (Visayan and Tagalog: "king in the mountain"). In this tradition, an ancient king lies sleeping within a mountain and is expected to wake at propitious moment to free the land from foreign invaders (Mojares 1974; Ileto 1979; Motifs A571, Culture hero asleep in mountain; A580, Culture hero's expected return; A581.2, Culture hero returns and aids followers in battle). The story of the sleeping king gained further impetus in the revolutionary period of the late-nineteenth century when the king was more explicitly identified with Philippine national independence (Ileto 1979, $125,234)$.

Despite the clear metaphorical power of Philippine recuperation narratives, materialistic and literal interpretations should not be dismissed out of hand. After all, part of what makes such stories compelling is the conviction with which they are recounted and the immediacy of their subject matter. Over the years, stories of lost treasure in the southern Philippines have been told to me without equivocation. Lucky treasure-finders were often identified by name, and material evidence of past excavations pointed out in the landscape: a heap of displaced earth on the edge of a mountain slope, an uneven house post, a ceramic fragment retrieved from a cave. ${ }^{10}$ Unregulated treasure hunting for Japanese gold has even led to appeals from prominent archeologists to preserve important cave sites from reckless disturbance (Ronquillo 1995). Indeed, many Boholanos are inclined to speak of the lost bell as a literal artifact and at least two attempts have been made to reclaim it. In the 1930s, Bohol's Provincial Vice Governor 
Timoteo "Iyo Tiyo" Butalid headed an expedition to raise the bell from where it was presumed to lie at the confluence of the Biga and Abatan Rivers. Butalid was himself an amateur folklorist who together with Domingo Torralba contributed several cave stories from Bohol to H. Otley Beyer's unpublished compilation of Filipino ethnography in 1916 (Torralba and Butalid 1916). A more recent venture was an informal exploration of the Inambacan Cave near Antequera in 1985. The team consisted of Dennis Drake (a former Peace Corps volunteer and now director of Bohol's International Deaf Education Association), another American by the name of Stephen Williams, and the local columnist Jes Tirol. In Drake's recollection, Tirol's motivation for joining the group was to search for a lost bell (Kelly 2012a, 45-49). As water from the Inambacan Cave ultimately flowed into the Abatan River, Tirol possibly imagined that the cave itself was a plausible hiding place for the bell. What he claimed to find instead were writings carved on the wall of the cave which he was able to photograph. Four years later he reexamined his photographs and interpreted the writings as being both Eskayan and Ancient Hebrew, estimating them to be 1300 years old (Tirol 1989a, 1989b); they have not yet been corroborated or archeologically verified.

At this time, the "discovery" of the Eskaya community was still recent in the public imagination. No analysis of the script or language had been made and the debate about the group's origins was taking place in a politically sensitive climate. In the aftermath of the Marcos dictatorship, critics were still in the process of gleefully debunking the Tasaday, a "lost" indigenous community of Mindanao that had supposedly been invented by the regime's allies as a propaganda tool (see especially Berreman 1992; Iten 1992; for a selection of counter-critiques see Dumont 1988; Molony 1992; Lee 1992; Nabayra and Rogel-Rara 1992; Reid 1992; Hemley 2004; Kelly 2014). In this national context, the fortuitous discovery of "ancient" Eskayan 
writings provided a timely proof of the group's long occupation of Bohol and a legitimization of their disputed indigenous status.

Literal interpretations of the bell as a discoverable artifact may comfortably coexist with moral or supernatural readings. With its limestone composition and dense network of underground caves, Bohol has its fair share of stories about caves, frequently presented as supernatural sources of generosity (Motif N512, Treasure in underground chamber [cavern]). A common tale is of earthenware jars and plates found inside the mouth of a cave, which are borrowed by locals for special events but always faithfully returned. Inevitably, an individual fails to give back a plate or jar resulting in the repossession of all the borrowed goods and the closure of cave's mouth (for descriptions of this narrative elsewhere in the Philippines see Ratcliff 1949; Meñez 1978; Alburo 1980; compare Motifs F353, Kettle borrowed from fairies and not returned, and F358, Money borrowed from the fairies and not returned on time).

These stories are morally instructive in their reinforcement of the principle of reciprocity, but they also serve as explanations for the unaccountable possession or loss of material resources. As the bell-hunting Vice Governor Timoteo Butalid put it, “The people attributed all cases of loss to these caves [of Bohol]" (Torralba and Butalid 1916). Tellingly, in one version of the "lender" tale, recorded by Erlinda Alburo, the objects take the form of modern silverware and chinaware, sourced from America by a supernatural entity (1980).

In her ethnography of Bohol's neighboring island of Siquijor, Hannah Bulloch observed that luck in the form of unanticipated wealth is occasionally attributed to the benevolent actions of supernatural beings known as engkanto (via Spanish encanto "magic spell"). Among these beings, the so-called puting dwende ("white dwarves") are thought by some to leave money around the house when treated with respect but other engkanto require more propitiation. If 
granted ritual offerings they may reciprocate with money and good luck but when offended they are also known to make off with the material property of humans (2009, 130; see also Pajo 1954, 138-139; ATU 503, The gifts of the little people). Consistent with many Filipino folk beliefs, there is no clear ontological division between the "real" and the supernatural, which are seen to materially interact in the same realm and on the same terms.

George Foster (1967) and Shirley Arora (1987) have reported virtually identical narratives of lost treasure and generous caves from communities in Mexico. Whether these similarities can be attributed to the long trade and political connections between Mexico and the Philippines in the era of Spanish rule is not my concern here. What is of more interest are the shared social circumstances in which these stories are circulated. As in the Philippines, the Mexican stories are presumed by their narrators to be true accounts and are sometimes associated with periods of political upheaval (e.g., the Mexican Revolution). Attempts at locating or retrieving treasure are mostly unsuccessful, but a few cases can always be found of inexplicably wealthy individuals who are identified as having been successful. Indeed, the Mexican treasure is similarly predestined to be found by a rightful owner, and misfortune awaits undeserving claimants. For Foster these tales serve to maintain the economic worldview of static peasant economies since they "account for wealth that can be accounted for in no other manner" (1967, 42). Developing Foster's economic interpretation Arora drew attention to dimensions of personal morality and autobiographical reflection, wherein the failure to obtain treasure helps to "mediate the disparity between aspirations and achievement, between what might have been and what actually is" making the failure "understandable, tolerable, even acceptable, to the narrator as well as to the audience" $(1987,91)$. 


\section{"The White Bell" of the Eskaya}

A tension between reality and aspiration is in evidence in a written Eskaya rendition of the Philippine lost-bell narrative, conventionally entitled "The White Bell."11 However, in contrast to the Mexican treasure stories in Arora's reading, "The White Bell” does not make failure tolerable; rather it postpones the consummation of (inevitable) future success after a period of temporary hardship, offering an insight into the particular uses of Philippine recuperation narratives. "The White Bell" is not among the canonical texts included in the traditional Eskaya curriculum, which means that written copies of it are relatively scarce. I am relying principally on a document supplied by Gemina Palma of Cadapdapan, originally prepared by the late Eleuteria Faustina Viscayda; an incomplete final fragment has been replaced with a text belonging to Decena Nida Palma Salingay who also assisted with the translation and interpretation of the entire narrative. I subsequently made a partial interlinear translation of the story for the purposes of linguistic analysis. ${ }^{12}$ The full text of "The White Bell," with its Visayan translation and Roman transliteration, is too large to include here, but can be accessed at the Pacific and Regional Archive for Digital Sources (PARADISEC) along with its interlinearization (to the best of my knowledge, no other English translations are yet available). ${ }^{13}$ The following represents a narrative summary of the story in English. Note that I have retained Eskayan words (in italics) wherever these are left untranslated in the original Visayan text:

The White Bell

The Spanish arrived in the Philippines between AD 600 and AD 677. By 1777 a war broke out which by 1804 had become a battle between the indigenous biriki ("priests") and the Spanish friars. The two sides had different belief systems. The biriki believed in miracles and venerated an entity known as Salbadur Sunu, whom the Spanish denounced 
as an araara ("false god"). During this conflict, an indigenous priest known as Tumud the Shaman received a vision of how to capture a white bell hanging in the tower of a Spanish church in Malabago. He climbed the tower with a small rope and tied one end to the foot of a bird, and the other to the loop of the bell. The local population, divided between baptized Christians and followers of the indigenous religion, gathered on the floor of the church to witness Tumud's daring. Using his faith in Salbadur Sunu, Tumud intoned the "language of God (Ara)." The parish priest, Fr José Maria, countered this with his friar's faith in Christianity and used Latin, the "language of Christ." Tumud's words prevailed and the bird took flight, towing the bell aloft. It flew to where a creek known as the Abatan flowed into the river at which point the iron fetter of the bell's clasp turned to water and the bell sank into the depths. The worshippers of Salbadur Sunu, who had not submitted to baptism, rejoiced at the recovery of their bell and vowed to die in defense of their motherland. Tumud sent his followers into the forests to fight against the friars. He told them that the bell could only be recovered from the river when those who have died for it are resurrected. If anyone should try to obtain the bell before this time, a mighty flood would issue from the bell's clasp, bringing death to thousands.

\section{$<$ Figure 5 here. $>$}

On the surface, “The White Bell" presents a clash of belief-systems between locals and colonists. The Spanish are followers of Christ while the Boholanos under Tumud the Shaman, follow Salbadur Sunu, glossed by Eskaya readers as the Santo Niño or "Holy Child," an important Catholic icon in the southern Philippines. ${ }^{14}$ Here, however, Salbadur Sunu is also interpreted by Eskaya readers as a kind of indigenous Christ figure who visited Bohol before the 
arrival of Spanish missionaries. The Spanish faith is portrayed as deficient, and the friars as incapable of belief in miracles. But Tumud's native epistemology is unencumbered by Spanish dogma and he is able to access the miraculous. Language is central to the contest. The "language of God"-presumably but not explicitly Eskayan — is pitted against Latin, the "language of Christ." ${ }^{\text {15 }}$ Tumud's language prevails and the bell is miraculously seized only to be sunk in the river to prevent its recapture.

As mentioned above, Eskaya are mostly members or descendants of members of the Iglesia Filipina Independiente (Philippine Independent Church) founded by Fr Gregorio Aglipay in the aftermath of the Philippine-American War (1899-1902). With its nationalist, revolutionary, and anticolonial agenda, the "Aglipayan church" as it is also known, achieved widespread popularity in the early twentieth century, attracting millions of followers especially in Luzon and Mindanao (Dauncey 1906, 209; de Achútegui and Bernad 1961). The fact that many of the church's staunchest adherents were former nationalist leaders, including Gregorio Aglipay himself, exacerbated the unease felt by the American colonists toward the new movement. Soon enough the contentious issue of church property presented an obvious flashpoint for conflict. Aglipayan priests and congregations claimed rights over the church buildings they had come to occupy, arguing that the buildings never truly belonged to Rome given that they had been constructed with Filipino labor. But by 1906, the Iglesia Filipina Independiente was already in steady decline. US negotiations with the Vatican, together with successful court actions brought by the Roman Catholic Church, resulted in the expulsion of Aglipayan congregations from the buildings they had come to occupy.

In Bohol the very earliest converts to the church were found amongst the Biabas community of Mariano Datahan, and the movement spread to surrounding villages and lowland 
towns of the southeast. The reclamation of church property is, arguably, a salient theme in Datahan's rendition of "The White Bell" and while church occupations by Aglipayans are not recorded in Bohol, a curious parallel to Tumud's heroism took place to the south of the island. In 1908 it was reported to the Philippine Commission that Aglipayan activists on the Quimaya River in Misamis Oriental, Mindanao, had removed the bell from their local Roman Catholic church and installed it in their own church where it remained until American administrators intervened (Philippine Commission 1909, vol. 1, 205).

Eskaya readers I interviewed had not heard of this incident in Misamis Oriental but expressed no surprise that such an event had taken place. Nonetheless, readers were not immediately inclined to associate Tumud's reclamation of the bell with the Aglipayan rejection of Rome and appropriation of church property. Instead, "The White Bell” was most often interpreted as an accurate record of a verifiable historical incident and its moral force lay in the recognition that Boholanos were the true bearers of the Christian faith. Contrary to orthodox Aglipayan doctrine, it is common for Eskaya to express the view that Christianity existed in Bohol prior to its later introduction by Spanish missionaries. Moreover, Eskaya Christianity was propagated as a consequence of direct evangelization by Christ himself, in the guise of the Santo Niño. Indeed, the notion that the Santo Niño was present in the Philippines prior to Spanish contact resonates with popular Visayan folklore surrounding the famous Santo Niño statue housed at the Basilica Minore del Santo Niño in Cebu City. While historians agree that the miraculous statue was a gift from Ferdinand Magellan to Rajah Humabon in 1521, a number of local legends maintain that the icon is an ancient artifact pre-dating Magellan's visit (Abellana 1960; Quimat 1980; Vano 1998; cited in Bautista 2010). 
The historical reframing of the Santo Niño as a pre-Hispanic journeying Christ permits the Eskaya to reject Catholicism, tainted by its association with Spanish dominance, while retaining Christian belief as an authentically native worldview. ${ }^{16}$ For Eskaya readers, "Tumud the Shaman" is identified specifically with the Boholano rebel Tamblot, mentioned earlier, whose insurrection against Spanish occupation in 1621 had a powerful religious motivation. Under Tamblot's leadership, local shamans encouraged the people of Bohol to abandon Christianity, and recruits to the cause were promised invulnerability to Spanish muskets. The rebels set about desecrating religious imagery, and as more communities joined the movement, there began a steady migration into the wild upland interior (Sturtevant 1976, 79-80; Romanillos 1997, 3). For Eskaya readers, however, it was not Christianity itself that Tumud — or Tamblotrejected but the illegitimate version introduced by Spain. In the story, the Spanish denounce the native faith in the Santo Niño (Salbadur Sunu) as the worshipping of a false god. Indeed, the Visayan counterpart of the Eskayan word araara ("false god") is dyusdyus, a reduplication of the Spanish Dios ("God"), and was used as a term of disparagement for the militant religious movements that proliferated in the revolutionary period and after (and with whom the Eskaya came to be associated). The contest of languages in "The White Bell" is a proxy for a religious duel between rival orthodoxies. Banned by Spanish priests, the true native language of Bohollike the true faith it encapsulates_rises up to defeat the interlopers. The bird summoned by Tumud is viewed by Eskaya readers as a miraculous incarnation of the Santo Niño, intervening on behalf of the faithful. Although Tumud wins the contest of faiths, the Spanish are not vanquished. The capture of the bell is merely a reprieve and the rebels flee to the forest to continue their resistance. Today, many Eskaya see themselves as direct successors of Tamblot's 
rebels, the unbaptized Boholanos who, having fled into the forest, never submitted to foreign rule.

Eskaya readers could not explicate all the details in the story. No account was given for the whiteness of the bell: the Eskayan word idlak is translated into Visayan as ugis ("white"), a term often used to describe a desirable fair complexion or to designate Europeans generally.

Such a racial designation would make sense, given that the bell originally belonged to a Spanish church. Neither was it known why the dates for Tumud's rebellion (1777 and 1804) did not coincide with that of the Tamblot uprising (1621); I have argued elsewhere that dates in Eskaya literature serve a primary linguistic function as markers of "pastness" (Kelly 2012a), or what Reynaldo C Ileto has referred to in a related context as "biblical time" $(2011,250)$. Nor was there any agreed account of why "the language of Christ" (Latin) and "the language of God" (Eskayan) were set in opposition, although one reader suggested that these were not opposing languages in and of themselves, but simply linguistic weapons in the hands of competing actors; the notion that words possess the power to inflict physical harm is widespread in the Philippines (Meñez Coben 2009, 4). It is not these details, however, that Eskaya readers remark upon during discussions of the tale. At its heart, the story was interpreted as a (perhaps imperfect) historical record vindicating the keepers of Bohol's true faith and the agents of native resistance.

\section{Conclusion: The Ever-Resounding Bell}

As we have seen, the story of "The White Bell" is not exclusive to the Eskaya and its literal interpretation as a lost but discoverable artifact is widespread in Bohol. When the Eskaya first came to public attention in 1980, two of the earliest reports by interested outsiders noted that the community possessed carved wooden tablets that told of Bohol's lost silver bell and that efforts 
were afoot to analyze these texts with a view to locating it (Ramos 1980; Cuizon 1980). But the popularity of literal interpretations of the lost-bell narrative by no means undermines its resonance as a recursive metaphor. After all, while other Filipinos were supposed to have been losing their literary heritage to the Spanish bonfires, Pinay took the precaution of hiding Eskaya writings in a cave, to be heroically rediscovered by Mariano Datahan. In turn, this rediscovery led to the recuperation of Bohol's putative indigenous language and culture. Non-Eskaya Boholanos participated in the same kinds of recuperation narratives when they characterized the Eskaya themselves as a "lost" people awaiting "discovery" by outsiders. The earlier discovery of Pinay's language was poignantly reenacted when the local historian Jes Tirol went looking for the lost bell but instead discovered Eskayan writings in the depths of the Inambacan Cave. No doubt, more discoveries and rediscoveries lie in wait.

Hanging high above the population, bells cannot help drawing attention to themselves, even if the meanings attributed to them are rarely stable. Bells are rung to announce a Mass or a wedding, yet they also give notice of a death or warn parishioners of impending danger. The resounding bell unites the faithful in a call to worship, but — as in Bicol and Mindoro Orientalits sound draws the rapaciousness of enemy heathens. Interpretations of bell stories are similarly polyvalent. In the Eskaya rendition, the bell operates as a token of rightful native ownership. Its mechanical role is to summon the population, a function that is reenacted in Tumud's incantation of Eskayan words summoning the Santo Niño in the guise of a bird. The bird's deliberate submersion of the bell in the river entails a material loss to its legitimate owners but this loss is understood as strategic and temporary_retrieval is possible at an unspecified future time by those who are morally entitled to reclaim it. In this way, the white bell narrative reinforces the moral dimensions of other more proximal experiences of loss and deferred recuperation: the loss 
of Filipino labor and its reclamation by Aglipayans, and the loss of Bohol's "true" native language and culture and its glorious revitalization by Mariano Datahan.

Amongst all the controversies over cultural authenticity, what the Eskaya community appears to demonstrate - with its avowedly invented traditions of language, script and literature - is that nothing is ever truly created de novo. Access to an immaculate native agency is always within the grasp of true believers, glinting under the surface of the ordinary world and awaiting recovery.

Max Planck Institute for the Science of Human History

Jena, Germany

\section{Acknowledgments}

Special thanks to Decena Nida Salingay for assisting with the analysis and interpretation of "The White Bell," and to Hannah Bulloch for commenting on an early draft of this paper.

\section{Notes}

2. This population figure is the conventional estimate provided by Eskaya leaders and the National Commission on Indigenous Peoples in Bohol, although there is no survey or census data to support this claim. The only study to have provided a precise figure puts the population at 
739 (Anania 2010) but it is not clear whether this number applies to all Eskaya people or only to those living within the municipality of Pilar.

3. In this paper, the term "Eskayan" is used to designate the language while "Eskaya" is reserved as a qualifier for other elements of Eskaya culture.

4. It is worth briefly remarking on the congruence of the name "Pinay" with the Tagalog/Visayan word pinay, a popular term for a Filipino woman; the masculine counterpart is pinoy. The words pinay and pinoy have patriotic overtones and are indeed derived from the final two syllables of Pilipina or Pilipino combined with the affectionate diminutive suffix $-y$. While I am confident that the culture hero Pinay long predates the relatively recent emergence of the colloquialism pinay ("Filipina"), it is interesting that younger Eskaya scribes are now beginning to question whether Pinay might have been female. Since Eskayan and Visayan do not mark grammatical gender in non-borrowed terms, the gender of Pinay is allowed to remain ambiguous although he is always depicted as a man in Eskaya visual imagery. In my heuristic usage I have defaulted to the more conservative view and referred to Pinay with masculine pronouns in English. For a fuller ethnographic treatment of gender in the Eskaya community see Estorba (2006).

5. For a linguistic explanation of this argument see Kelly (2012c, 200).

6. In her discussion of whether Eskaya literature fits classic understandings of "folklore," Ma. Cristina Martinez writes that "[t]he Eskayan texts are definitely not amorphous bodies of oral narrative floating around in peasant villages waiting to be documented/written down by folklorists from universities" (1993). 
7. Otley H Beyer writes: "It cannot be said that such writings did not exist, since the early Filipinos were even more literate than the Mexicans; they used syllabaries of Indian origin. One Spanish priest in southern Luzon boasted of having destroyed more than three hundred scrolls written in the native character" (1979). However, no reference is given to this claim and I have not found any supporting scholarship for it.

8. After this paper passed review, eight additional lost-bell stories from the Philippines have come to my attention in Damiana L. Eugenio's Philippine Folk Literature: The Legends (1987, 412-427). Seven of these are variants of the Moro pirate narrative, while the eighth, from Pangasinan, tells of a giant who stole a village church bell but then fell into a river and was dragged to its depths by the weight of the bell.

9. This reading resonates with another Philippine narrative of loss and deferred recuperation, encapsulated in the popular Kapampangan folksong "Atin ku pung singsing” ("I have a ring"): "I have a ring/ It is the center of my life/ I inherited it/ from my mother/ I pretended to hide it/ in a container./ It disappeared / without my noticing./ The dirt that piled up in my soul/ Reaches the highest heavens./ I crossed my hands/ across the table. /Whoever finds/ this ring of my heritage/ my impoverished heart/ will follow him forever.” Kampapangan scholar Michael Pangilinan draws attention to the line "Meyala ya iti" ("It disappeared") which contains within it the word aláya ("that which is not there"; Pangilinan 2014). Pangilinan reads this as an intertextual pun referencing a sequence of Kampapanga proverbs that define the utility of objects based on their negative space: "A cup is not a cup, if not for that which is not there (aláya). A house is not a house if not for that which is not there. A person is not a person if not for that which is not there." The ring, of course, is an almost prototypical example of an object structured 
by its own aláya. That the lost ring of the folksong was inherited reinforces the implication that the singer's quest is ultimately to recuperate an intrinsic but intangible heritage.

10. I was by no means the first foreign visitor to Bohol to be regaled by lost-treasure stories. Anthropologist Axel Borchgrevink gives an account of various quests to find General Yamashita's gold during his fieldwork in a village on Bohol's south coast in the 1990s. Among those suspected of attempting to retrieve the gold were members of a Japanese reforestation and crew, the local mayor, and Borchgrevink himself who was subtly cross-examined on several occasions. As Borchgrevink puts it: "The theme of outsiders, particularly foreigners, looking for treasure under the cover of other purposes and, it was implied, stealing it from the rightful owners was recurrent in many treasure stories. Foreigners were seen as having clear advantages, as the local people lacked the sophisticated equipment, like metal detectors, seen as necessary for such searches" $(2014,104)$.

11. An alternative title is "The Story of the Old Philippine Visayas" ("Witim ya rimuy miriklan Visayan Pilipin"; “Kasugiran sa mga karaan Visayan Pilipin”).

12. I am indebted to Noelyn Dano for assistance with the interlinearization of the Visayan layer.

13. See "Eskaya manuscripts from Cadapdapan, Bohol," in The Eskaya Digital Archive, http://catalog.paradisec.org.au/collections/PK2/items/04.

14. In transcriptions of the text, Salbadur Sunu is sometimes written "Salbadur Munu" and often the two spellings can alternate within the same document. I have been assured by Eskaya readers that this nonetheless refers to the same entity. What it suggests, however, is a 
derivation from the Spanish salvador del mundo ("savior of the world"). Equally, "Sunu" could be understood as a contraction of "Santo Niño."

15. Wolff (1972) defines the Visayan word latin as "1 Latin. 1a special k.o. prayer with magical effects." Both senses are apparent in the context of its use in "The White Bell" where the friar's prayer is presented as discursively equivalent to the shaman's spell.

16. In her discussion of the Eskaya text Ang pagtulun-an sa Bisayas, Martinez (2003) arrives at a similar conclusion about the symbolic function of the Santo Niño icon for the Eskaya.

\section{References}

Abellana, Jovito S. 1960. "Bisaya Patronymesis Sri Visjaya.” Unpublished MS. Archived at the Cebuano Studies Center, the University of San Carlos, Cebu City.

Abregana, Brenda. 1984. "Eskaya: The Living Fossil Language in Bohol.” Focus Philippines, July 28 .

Aguilar, Celedonio G. 1994. Readings in Filipino Literature. Quezon City: Rex Book Store. Alburo, Erlinda Kintanar. 1980. "A Study of Two Cebuano Legends: The Lost Lender and Maria Cacao." Philippine Quarterly of Culture and Society 8 (1): 44-59.

Anania, Joseph. 2010. Eskaya Tribe Cultural Heritage Preservation and Development Program: Pilar, Bohol. Pilar, Bohol: LGU-Pilar.

Anderson, Benedict. 1998. The Spectre of Comparisons: Nationalism, Southeast Asia, and the World. London and New York: Verso. 
Arora, Shirley. 1987. "Memorate as Metaphor: Some Mexican Treasure Narratives and Their Narrators." In Perspectives on Contemporary Legend II, edited by Gillian Bennet, Paul Smith and J.D.A. Widdowson, 79-92. Sheffield: Sheffield Academic Press.

Aparece, Ulysses B. 2003. "Sukdan Curing practices in Anonang, Inabanga, Bohol: An Ethnography of Performance.” PhD diss., University of San Carlos, Cebu City.

Berreman, Gerald D. 1992. “The Tasaday: Stone Age Survivors or Space Age Fakes?” In The Tasaday Controversy: Assessing the Evidence, edited by T. N. Headland. Washington, DC: American Anthropological Association.

Beyer, Otley H. 1979. “The Philippines before Magellan.” In Readings in Philippine Prehistory, edited by Mauro Garcia, 8-34. Manila: Filipiniana Book Guild.

Borchgrevink, Axel. 2014. Clean and Green: Knowledge and Morality in a Philippine Farming Community. Quezon City: Ateneo de Manila University Press.

Bulloch, Hannah. 2009. "In Pursuit of Progress: Narratives of Transformation on a Philippine Island.” PhD diss., The Australian National University, Canberra.

Cannell, Fenella. 1999. "Introduction: Mountains and Plains." In Power and Intimacy in the Christian Philippines, 1-26. Cambridge: Cambridge University Press.

Consul, Stella Marie de los Santos. 2005. "Iniskaya: A Linear Linguistic Description.” PhD diss., Cebu Normal University, Cebu City.

Cuizon, Erma M. 1980. "Eskaya Archives: Bohol Community May Hold Clue to Bisayan Alphabet's Origin.” Tubod, December.

Dauncey, Campbell Mrs. 1906. An Englishwoman in the Philippines. London: John Murray. 
David, E. J. R, and Sumie Okazaki. 2006. “Colonial Mentality: A Review and Recommendation for Filipino American Psychology.” Cultural Diversity and Ethnic Minority Psychology $12(1): 1-16$.

de Achútegui, Pedro S, and Miguel A Bernad. 1961. Religious Revolution in the Philippines: The Life and Church of Gregorio Aglipay: 1860-1960. Vol. 1. Manila: Ateneo de Manila.

de los Reyes y Florentino, Isabelo. 1889. El Folk-lore Filipino. Manila: De Chofré.

Dumont, Jean-Paul. 1988. "The Tasaday, Which and Whose? Toward the Political Economy of an Ethnographic Sign.” Cultural Anthropology 3 (3):261-275.

Estorba, Regina. 2006. "Scribbling the Voice of a tende." Kinaadman 17 (1).

Eugenio, Damiana L. 1987. Philippine Folk Literature: The Legends. Vol. 3, Philippine Folk Literature Series. Quezon City: The U.P. Folklorists Inc, Folklore Studies Program, U.P. Diliman.

_.1993a. "The Origin of the Makopa (Iloko)." In Philippine Folk Literature: The Myths. Quezon City: University of the Philippines Press.

_.1993b. "Why the Macopa is Bell-Shaped (Oriental Mindoro)." In Philippine Folk Literature: The Myths, 451-453. Quezon City: University of the Philippines Press. Hemley, Robin. 2004. Invented Eden: The Elusive, Disputed History of the Tasaday. Pasig City: Anvil Publishing.

Hinlo, Aida. 1992. "Proposed Nonformal Education Program for the Eskayas of Bohol." MA thesis, Philippine Women's University, Manila.

Ileto, Reynaldo C. 1979a. Payson and Revolution: Popular Movements in the Philippines, 18401910. Quezon City, Metro Manila: Ateneo de Manila University Press. 
. 1979b."Tagalog Poetry and Image of the Past During the War against Spain." In

Perceptions of the Past in Southeast Asia, edited by A. Reid and D. Marr. Singapore:

Heinmann Educational Books.

.2011. "A Tagalog Awit of the 'Holy War' against the United States, 1899-1902.” In

Orality and Literacy: Reflections across Disciplines, edited by K. T. Carlson, K. Fagan

and N. Khanenko-Friesen. Toronto: University of Toronto Press.

Iten, Oswald. 1992. "The 'Tasaday' and the Press." In The Tasaday Controversy: Assessing the

Evidence, edited by T. N. Headland. Washington, DC: American Anthropological Association.

Kelly, Piers. 2012a. "The Word Made Flesh: An Ethnographic History of Eskayan, a Utopian Language and Script in the Southern Philippines." PhD diss., Canberra: The Australian National University.

.2012b. "Your Word against Mine: How a Rebel Language and Script of the Philippines was Created, Suppressed, Recovered and Contested." The Australian Journal of Anthropology 23 (3): 357-378.

.2012c. "The Morphosyntax of a Created Language of the Philippines: Folk Linguistic Effects and the Limits of Relexification." In Proceedings of the $42^{\text {nd }}$ Australian Linguistic Society Conference-2011, Australian National University, Canberra ACT, 24 December 2011, edited by M. Ponsonnet, L. Dao and M. Bowler. Canberra: ANU Research Repository, http://hdl.handle.net/1885/9401. .2014. "A Tasaday Tale in Bohol: The Eskaya Controversy and its Implications for Minority Recognition, the Indigenous Peoples Rights Act and the Practice of Cultural 
Research in the Philippines." Lumina: A Journal of the Southern Philippines 24 (2): 124.

.2016. "Introducing the Eskaya Writing System: A Complex Messianic Script from the Southern Philippines." The Australian Journal of Linguistics 36 (1):131-163.

Lee, Richard B. 1992. “Making Sense of the Tasaday: Three Discourses.” In The Tasaday Controversy: Assessing the Evidence, edited by T. N. Headland. Washington, DC: American Anthropological Association.

Logarta, Margarita T. 1981. “The Eskaya Cult: Children of a Lost Language.” Who, September 5.

Martinez, Ma. Cristina J. 1993. “Gahum ug gubat: A Study of Eskayan Texts, Symbolic Subversion and Cultural Constructivity." PhD diss., University of the Philippines, Manila.

Martinez-Juan, Ma. Cristina. 2003. "Double Marginalization and Speaking Back: A Reading of Three Post-Colonial Texts.” Philippine Quarterly of Culture and Society 31: 281-290.

Meñez, Herminia Q. 1978. "Encounters with Spirits: Mythology and the Ingkanto Syndrome in the Philippines." Western Folklore 37 (4): 249-265.

Meñez Coben, Herminia. 2009. Verbal Arts in Philippine Indigenous Communities: Poetics, Society, and History. Manila: Ateneo de Manila University Press.

Mojares, Resil B. 1974. "The Myth of the Sleeping Hero: Three Philippine Cases.” Philippine Quarterly of Culture and Society 2 (3):156-162.

Molony, Carol H. 1992. “The Tasaday Language: Evidence for Authenticity?” In The Tasaday Controversy: Assessing the Evidence, edited by T. N. Headland. Washington, DC: American Anthropological Association. 
Nabayra, Emmanuel S., and Amelia Rogel-Rara. 1992. “The Genealogical Evidence.” In The Tasaday Controversy: Assessing the Evidence, edited by T. N. Headland. Washington, DC: American Anthropological Association.

Ongsotto, Rebecca Ramilo, and Reena R Ongsotto. 2002. Philippine History: Module-Based Learning. Quezon City: Rex Book Store.

Orcullo, Proceso L. 2004. “The Eskaya Communities of Taytay, Duero Bohol: A Study of Change and Continuity.” PhD diss., Ateneo De Davao University, 2004.

Pajo, Maria Caseñas. 1954. "Bohol Folklore.” MA thesis, University of San Carlos, Cebu City. Pangilinan, Michael R.M. 2014. Atin ku pûng singsing. Unpublished MS.

Payot, Alberto A. 1981. “Bisayan Eskaya: Karaang pinulongan sa Bohol?” Bisaya, June 3.

Peralta, Jesus T. to Alfonso B Catolin, Feburary 23, 2005. NCIP Bohol Archives.

Philippine Commission. 1904. Fourth Annual Report of the Philippine Commission: 1903. In Three Parts, vol 3. Washington: Government Printing Office. 1909. Report of the Philippine Commission to the Secretary of War: 1908, vol 1. Washington: Government Printing Office.

Quimat, Lina. 1980. Glimpses in History of Early Cebu. Cebu: The University of San Carlos. Ramos, Salome. 1980. "National Book Week Project Proposal Addressed to Mrs. Corazon M Nera, FAPE Library, Legaspi Village, Makati, Metro Manila.” Bohol Provincial Library Archives.

Ratcliff, Lucetta K. 1949. "Filipino Folklore.” The Journal of American Folklore 62 (245): 259289. .1951. "Some Folklore from Bicol Province, Philippine Islands." Western Folklore 10 (3): 231-236. 
Reid, Lawrence A. 1992. “The Tasaday Language: A Key to Tasaday Prehistory.” In The Tasaday Controversy: Assessing the Evidence, edited by T. N. Headland. Washington, DC: American Anthropological Association.

Rizal, José. 1886. Noli me tángere. Valencia and Madrid: F. Sempere y Compañía.

—_ [1889-1890] 1972. The Philippines a Century Hence [Filipinas dentro de cien años]. In Alzona, Encarnación (trans.), Political and Historical Writings, vol. 7. Manila: National Historical Institute.

Romanillos, Emmanuel Luis A. 1997. The Dagohoy Rebellion Revisited. Quezon City: University of the Philippines-Diliman.

Ronquillo, Wilfredo P. 1995. “Anthropological and Cultural Value of Caves." Philippine Quarterly of Culture \& Society 23: 138-150.

Root, M. P. P. 1997. Filipino Americans: Transformation and Identity. Thousand Oakes, CA: Sage.

Sturtevant, David R. 1976. Popular Uprisings in the Philippines, 1840-1940. Ithaca: Cornell University Press.

Thomas, Megan C. 2012. Orientalists, Propagandists and Ilustrados: Filipino Scholarship and the End of Spanish Colonialism. Minneapolis and London: University of Minnesota Press.

Thompson, Stith. 1955-1958. Motif-Index of Folk-Literature: A Classification of Narrative Elements in Folktales, Ballads, Myths, Fables, Mediaeval Romances, Exempla, Fabliaux, Jest-Books and Local Legends. 6 vols. Copenhagen: Rosenkilde and Bagger.

Tirol, Jes B. 1989a. “Bohol: A New Jerusalem?” The Bohol Chronicle, March 19. .1989b. "Bohol: A New Jerusalem?: $2^{\text {nd }}$ Installment." The Bohol Chronicle, March 26. 
_.1993. "Eskaya of Bohol: Is it a Tribe?" The Bohol Chronicle, June 20.

Tirol, Victoriano B. 1968. "A Study of Bohol Literature (Hero-Tale, Drama, Poetry and Short Story).” PhD diss., The Pontifical and Royal University of Santo Tomas, Manila.

Torralba, Domingo, and Timoteo Butalid. 1916. "Some Stories Connected with the Caves of Bohol," In Ethnography of the Bisaya Peoples, vol. 3, edited by O. H. Beyer: Paper no. 71. Box 103.

Torralba, Milan Ted. 1991a. "Description of Preliminary and Future Data Elicitation for Linguistic Analysis of the Eskaya Language of Bohol.” Paper submitted in partial fulfilment of the requirements for the subject of Linguistics 703 (Field Methods in Linguistics). M.A. Linguistics. The Pontifical and Royal University of Santo Tomas. .1991b. "The Morphology of the Eskaya Language." Term paper submitted in partial fulfilment of the requirements in LNG 704 (Morphology \& Syntax), The Pontifical and Royal University of Santo Tomas.

.1993. "A Linguistic Investigation into the Origin and Structure of the Eskaya-Bisayan Ethnolanguage." Thesis proposal presented to the Graduate School, The Pontifical and Royal University of Santo Tomas.

Uther, Hans-Jörg. 2004. The Types of International Folktales: A Classification and Bibliography, Based on the System of Antti Aarne and Stith Thompson. Helsinki: Suomalainen Tiedeakatemia and Academia Scientiarum Fennica.

Vano, Manolo O. 1998. "Folk Religion and the Revolts in the Eastern Visayas." In Kasaysayan at Kamalayan: Mga piling akda ukol sa diskursong pangkasaysayan, ed. N. M. R. Santillan and M. P. B. Conde, 101-21. Quezon City: Limbagang Pangkasaysayan. Wolff, John U. 1972. A Dictionary of Cebuano Visayan. Ithaca: Cornell University. 
Zaide, Gregorio F. 1959. History of the Filipino People. Manila: Villanueva Book Store.

PIERS Kelly is a linguistic anthropologist at the Max Planck Institute for the Science of Human History in Jena, Germany. His interest in Philippine folklore arose during his employment as a Language Research Officer for the National Commission on Indigenous Peoples (Philippines) from 2005-2006. 